\title{
Antonio Brand, um compromisso por toda a vida
}

\author{
Pe. Georg Lachnitt*
}

Comentar a vida de Antonio Brand é uma questão tão ampla e profunda que, como tantos outros, limitar-me-ei a sublinhar apenas alguns aspectos, na perspectiva do missionário de coração.

Não tendo encontrado na vida religiosa um campo adequado aos seus anseios, Antonio aliou-se a alguns outros companheiros na recém-fundada Operação Anchieta (OPAN) para ser missionário entre os indígenas. Encontrou-se com os companheiros do Conselho Indigenista Missionário, organização fundada pouco depois da OPAN, somando esforços com eles no campo imenso dos povos indígenas de Mato Grosso do Sul. Tornou-se companheiro próximo e comprometido com os Kaiowá, por meio dos quais conheceu a realidade de Caarapó, campo de ação que não abandonaria mais.

Tendo que escolher entre OPAN e CIMI, uma vez que a OPAN preferiu a independência da Igreja, ficou no CIMI, dando assim uma declarada opção missionária em nome da fé no Senhor Jesus. Assumiu pouco depois a coordenação do CIMI-MS com sede na Vila São Pedro, Dourados, onde morava sem, contudo, tomar distância da base indígena, pois a vila São Pedro se encontrava no meio da realidade indígena. O rico acervo de documentação hoje em Dourados dá prova da atividade consistente do grupo que Antonio soube reunir, uma característica típica, a de formar grupos consistentes e reciprocamente comprometidos.

Como coordenador regional, em 1983, foi eleito secretário nacional do CIMI por duas vezes, consecutivamente até 1991, no qual, depois da eminente figura Dom Erwin Kräutler, Presidente do CIMI, era o primeiro e dinâmico missionário. Sua capacidade de organizar, criar grupos e cultivar alianças ao redor do mesmo ideal foi posta à prova, de modo exímio, por ocasião da Constituinte de 88 . Nesse grupo se encontrava o advogado do CIMI, Júlio Gaiger, posteriormente presidente 
da FUNAI, e que terminou sua carreira num acidente de trânsito. Com Dom Erwin conseguiram aproximar-se do Senador Jarbas Passarinho e fazer dele um aliado da causa indígena na Constituinte. Quando O CIMI foi atacado durante uma semana inteira caluniando seus objetivos e sua atuação, Dom Luciano Mendes de Almeida, presidente da CNBB, foi ao Congresso com Antonio, onde este fez uma brilhante defesa dos objetivos do CIMI e desmascarou com argumentos sólidos as reais intenções da difamação.

Tendo terminado sua missão brilhantemente, Antonio preferiu retomar outra arma de defesa dos povos indígenas, a via acadêmica. A pesquisa final de tese de doutorado em história o levou a ter contato mais profundo com todas as comunidades indígenas de MS, recebendo testemunho e documentos comprobatórios de suas terras. Não é por nada que os opositores o chamaram de criador das terras indígenas não mais existentes. Essa acusação cheia de malícia, porém nada mais era do que depositar por escrito a experiência de deportação de tantos hoje anciãos que a viva voz comprovaram a sua origem com detalhes nítidos.

Tendo concluído sua tese de doutorado, os dirigentes da Universidade Católica Dom Bosco (UCDB), compreendendo o valor de tão exímio historiador pela causa indígena, a qual tinha sido a razão da fundação da Inspetoria Salesiana de Campo Grande - Missão Salesiana de Mato Grosso, em 1894, convidou o Professor Dr. Antonio Brand a fazer parte da equipe dos docentes. No mesmo tempo, encontrou no recém-fundado Núcleo de Estudos e Pesquisas de Populações Indígenas (NEPPI), seu novo campo de ação em favor dos povos indígenas. Com o novo grupo formado, enfrentou, no entanto, a problemática situação desses povos de maneira científica, e rigorosamente, procurando consolidar qualquer declaração e os sempre crescentes campos de ação com argumentos sólidos nos diversos aspectos de sua respeitável equipe.

Seu nome tornou-se conhecido, não apenas no MS contra os gananciosos de terras, mas mais amplamente. No mundo científico, seu grupo teve suficiente credibilidade para merecer o apoio a suas atividades com diversos projetos, pequenos e grandes, tudo era bem-vindo pela causa que defendia. Foi convidado ainda para participar do grupo maior em favor dos Guarani da América do Sul, no qual recebeu outras tantas pesquisas e contribuiu com suas próprias. Tudo isso foi sistematizado no Centro de Documentação Indígena Teko Arandu (CEDOC), centro este que continua a receber informações e as coloca à disposição de pesquisadores e também da Justiça no esforço de resolver a questão premente da recuperação das terras indígenas, indispensáveis para a sobrevivência física e cultural desses povos. Foi convidado também a participar da articulação de alto nível (Ministério da Justiça, MP, representantes dos agronegócios etc.) para procurar uma solução factível na atual situação de conflito, em que a proposta conciliadora de Antonio mereceu aplauso até 
dos opositores, menos um. Mais uma vez deu sua contribuição, cientificamente comprovada, para uma solução viável do conflito cada dia maior.

O já citado método de organizar equipes e distribuir as competências foi de fundamental importância quando todos, amigos e inimigos, foram surpreendidos pela sua morte repentina. Havia quem anunciasse o fim do NEPPI, seu consistente grupo de trabalho. Nada disso. A coordenação dos projetos já estava tão bem distribuída, que todos os projetos puderam continuar, garantindo segurança aos não poucos indígenas que foram incomodados por notícias assustadoras. Tudo foi organizado por Antonio de tal modo, consistente em equipe, que podia continuar sem o mínimo sinal de ter terminado o compromisso pelos direitos dos povos indígenas. Vemos nessa metodologia de Antonio o seu real compromisso pela causa e sem o mínimo sinal de sua autopromoção. Ele sempre olhava e sonhava para mais longe enquanto os coordenadores dos projetos se empenhavam na sua execução contando sempre com a sua real contribuição e presença.

A causa indígena, defendida por Antonio Brand pelo CIMI como órgão da Igreja, e pelo NEPPI, em nome da UCDB, continua viva atuando por tantos colegas pesquisadores, indígenas compromissados pela própria causa e por tantos missionários e missionárias em nome de sua fé no Senhor Ressuscitado. Que os Povos Indígenas também possam ressuscitar de sua situação de morte para uma vida de paz e harmonia!

Antonio Brand, somos herdeiros de sua tarefa! 
